Hydrol. Earth Syst. Sci. Discuss., 6, 1347-1383, 2009 www.hydrol-earth-syst-sci-discuss.net/6/1347/2009/ (C) Author(s) 2009. This work is distributed under the Creative Commons Attribution 3.0 License.
Hydrology and Earth System Sciences Discussions

open-access review for the journal Hydrology and Earth System Sciences

\title{
Intensity-Duration-Frequency and spatial analysis of droughts using the Standardized Precipitation Index
}

\section{Mohseni Saravi ${ }^{1}$, A. A. Safdari ${ }^{1}$, and A. Malekian ${ }^{2}$}

${ }^{1}$ Faculty of Natural Resources, University of Tehran, Karaj, Iran

${ }^{2}$ International Research Center for Coexistence with Desert, University of Tehran, Tehran, Iran

Received: 15 January 2009 - Accepted: 30 January 2009 - Published: 2 March 2009

Correspondence to: A. Malekian (malekian@ut.ac.ir)

Published by Copernicus Publications on behalf of the European Geosciences Union.

\section{HESSD}

$6,1347-1383,2009$

Intensity-Duration-

Frequency and spatial analysis of droughts

\section{Mohseni Saravi et al.}

\section{Title Page}

Abstract

Conclusions

Tables

14

4

Back
Introduction

References

Figures

$\rightarrow$

Close
Full Screen / Esc

Printer-friendly Version

Interactive Discussion 


\section{Abstract}

Precipitation deficit and its daily, seasonal and annual oscillations are inherent characteristics of Iran's climate. Droughts are generally characterized by a prolonged and abnormal moisture deficiency. In drought studies it is important to characterize the start and end of a drought as well as its intensity, duration, frequency and magnitude. The objective of this study was to analyze drought characteristics and to develop drought maps in the Karoon river basin, Iran. The Standardized Precipitation Index (SPI) was used in drought analysis based on the data for meteorological stations located inside or adjacent to the study area and three time scales including the 3-, 6- and 12-month SPI were evaluated. After determining the dry and wet periods, historical characteristics of droughts were identified and spatial distribution maps of droughts were plotted using GIS. Based on frequency distributions, drought durations and magnitudes were computed corresponding to 5, 10, 20, 50 and 100-year return periods. The Time scaleDuration-Frequency (TDF) and Time scale-Magnitude-Frequency (TMF) relationships poses. Drought spatial distribution maps show that extreme conditions dominate the southeastern regions of the basin. The efficiency of the SPI is determined by monitoring the drought of 1999 .

\section{Introduction}

20 Climate uncertainty is one of the major threats in contemporary water resources management. Water consumption is increasing in semiarid rural regions around the world, mainly due to developing agricultural activities. Moreover, the rapid growth of world population and uneven distribution of resources have served to escalate both the frequency and severity of natural hazards and disasters, especially in semiarid regions in precipitation decrease resulting in drought events that may negatively affect water
HESSD

$6,1347-1383,2009$

Intensity-Duration-

Frequency and spatial analysis of droughts

M. Mohseni Saravi et al.

Title Page

Abstract

Introduction

Conclusions

Tables

References

Figures

14

4

Back

Close

Full Screen / Esc

Printer-friendly Version

Interactive Discussion $\rightarrow$

$>$ 
resources and harm agricultural activities (Dalezios et al., 1991). In most parts of Iran, the availability of surface water is very important for agriculture. Thus analysis of droughts with respect to climate extremes is crucial in Iran.

Drought has no universal definition, but it is generally characterized by a prolonged 5 and abnormal moisture deficiency (Palmer, 1965; Dalezios et al., 1991). Drought is related to rainfall intensity, number of rainfall events and time lag between two rainy seasons, as well as climate factors such as high wind, high temperature or low relative humidity (Bordi et al., 2001). Wilhite and Glantz (1985) thoroughly reviewed dozens of drought definitions and they identified six major categories of drought definitions: 10 meteorological, hydrologic, climatological, atmospheric, agricultural and water management. Dracup et al. (1980) noticed several drought characteristics in all drought studies: onset, retreat, intensity, duration, frequency and magnitude. Drought is a "creeping phenomena" so an accurate determination of the onset or retreat is difficult (Wilhite and Glantz, 1985). Drought onset can be identified based on precipitation 15 statistics or by drought indices. Identifying a drought's withdrawal time is simpler than its onset, and depends on how drought is defined. Drought intensity can be measured by the departure of a climate index from its normal value, low flows in rivers or ground water levels or the effects on crops, flora and livestock (Girux, 2001). Drought duration is closely linked to its onset and withdrawal date and is sometimes expressed in terms of the number of consecutive days of no rain (Fig. 1). The frequency of an extreme event is usually expressed by its return period or occurrence interval, which may be defined as the average time lag between two events of the considered magnitude or larger magnitude (Dalezios et al., 2000). The magnitude of a considered drought event corresponds to the cumulative water deficit over the drought period (Thompson, 1999) and the average of this cumulative water deficit over the drought period is mean intensity.

HESSD

6, 1347-1383, 2009

Intensity-DurationFrequency and spatial analysis of droughts

M. Mohseni Saravi et al.

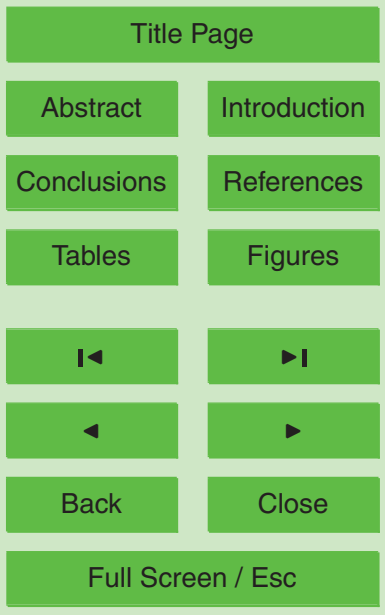

Printer-friendly Version

Interactive Discussion 
$D M=-\left(\sum_{i=1}^{n} S P / i j\right)$

$D M$ : Drought Magnitude

$n$ : number of months with drought event at $j$ timescale

$6,1347-1383,2009$

5 Different indices have been developed through the years to quantify drought intensity. Such indices are usually based on the precipitation deviation from the mean for a given period. The most commonly used indices are: Percent of Normal, Deciles, Standardized Precipitation Index (SPI), Palmer Drought Severity Index (PDSI), Crop Moisture Index (CMI) and Surface Water Supply Index (SWSI). This study was based 10 on the SPI. The SPI was developed by McKee et al. (1993) to quantify the precipitation deficit for multiple time scales (1, 3, 6, 12, 24, 48 months). This versatility allows the SPI to monitor short-term water deficits, such as soil moisture, important for agriculture production, and long-term water resources such as ground water supplies, stream flow and reservoir levels. Drought frequency decreases and its duration increases linearly as time scales decrease (McKee et al., 1995). The drought onset was detected at least one month in advance of the PDSI in the USA during the drought of 1996. This timeliness will be invaluable for improving mitigation response actions to drought-affected regions in the future (Hayes et al., 1998). The one month SPI (SPI-1) is analogous to Percent of Normal precipitation and reflects short-term conditions (National Drought Mitigation Center, 1999). There are extensive examples in the literature where quantitative assessment of droughts is done using the SPI (Girux, 2001; Bordi et al., 2001; Zenvettor, 2000; Abenza, 1999). The purposes of this study were to:

1. Assess the Standardized Precipitation Index's (SPI) capability to monitor historical droughts in the Karoon basin.

2. Analyze droughts in terms of their intensity, duration and frequency and their impacts in plotting drought maps of the Karoon basin.

\section{Intensity-Duration- Frequency and spatial analysis of droughts}

M. Mohseni Saravi et al.

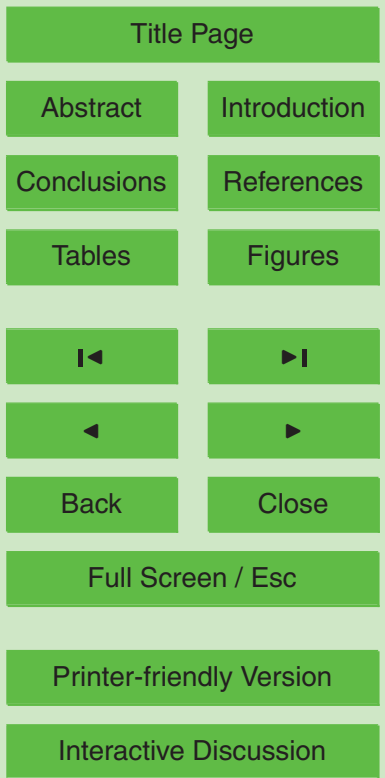


Data for 29 stations over the basin were used to obtain SPI time series, considering their overlapping period (1972-1999). The 3, 6 and 12-month SPI time series were used to determine drought characteristics and for plotting the drought maps.

HESSD

$6,1347-1383,2009$

Intensity-Duration-

Frequency and spatial analysis of droughts

Karoon is a major river basin located in southwestern Iran between $48^{\circ} 10^{\prime}$ and $52^{\circ}$ $38^{\prime} \mathrm{E}$ longitude and $30^{\circ} 20^{\prime}$ and $34^{\circ} 5^{\prime} \mathrm{N}$ latitude (Fig. 2). The catchment's elevation ranges from 0 to $4000 \mathrm{~m}$ above sea level. Climate conditions strongly depend on topography. Annual average rainfall ranges between $150 \mathrm{~mm}$ in the southern parts of 10 the basin to $1800 \mathrm{~mm}$ in the Koohrang Mountains, located in the north. As a result of diverse topography and climate conditions, the mean annual precipitation and temperature, mean number of rainy days per year and mean annual class A pan evaporation display high variability at different time scales (seasonal, annual and beyond).

\subsection{Input data}

Calculation of the SPI for a specific time period at any location requires a long-term monthly precipitation database. Monthly precipitation data were acquired from the Iran Meteorological Organization (IMO) and the Water Resource Research Institute. Twenty nine stations with 28 years of common recorded data (1972-1999) were selected to obtain: 1) the longest possible records for the basin; and 2) stations with the smallest amount of missing data. The number of missing data was very small and their values were estimated based on the correlation between stations. Data generation for a given station was accomplished by using a linear regression considering the station of highest correlation. The locations of the considered stations are shown in Fig. 2 and Table 2.

\section{Mohseni Saravi et al.}

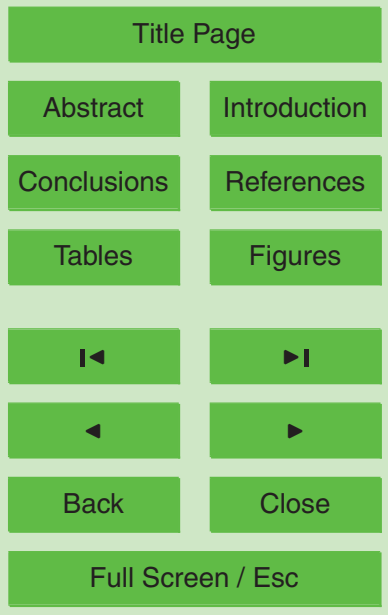

Printer-friendly Version

Interactive Discussion 
The Standardized Precipitation Index (SPI) is calculated in the following sequence. A monthly precipitation data set is prepared for a period of $m$ months and a set of averaging periods is selected as time scales of $j$-months where $j$ is $3,6,12,24$, or 48

5 months. These time scales represent arbitrary but typical time scales for precipitation deficits to affect the five types of usable water resources. The data set is moving in the sense that each month a new value is determined from the previous $j$ months.

Calculation of the SPI for a specific time scale at any location requires the good fit of a Gamma frequency distribution as the most likely probability function, to the data. 10 In other words, it is necessary to evaluate frequency distributions of the monthly data. Several theoretical distributions were tested for monthly rainfall data, such as: normal, two parameter log-normal, three parameter log-normal, two parameter gamma, Extreme Value Type 1 (Gumbel) and log-Pearson distributions. The Mean Relative Deviation test at $95 \%$ confidence level was applied to fit theoretical frequency distributions 15 to rainfall data.

Once the cumulative density function is established from the historic records, the probability of any precipitation data point is transformed to its corresponding value in normal distribution probability with a mean of zero and standard deviation of unity. This value is the SPI for the particular precipitation data point (Fig. 3).

$20 \quad$ McKee et al. (1993) used the classification system shown in Table 1 to define drought intensities based on the SPI. The SPI 3-, 6- and 12-month time series were computed for 29 stations with the same period of record (1972-1999) over the Karoon basin using the SPI software (McKee et al., 1993) as shown in Fig. 4. The historical database of droughts for each station and each time scale were identified and tabulated based on the computed SPI time series. Then Drought duration and their magnitude time series were computed for each station and time scale. These characteristics were used to develop Time scale-Duration-Frequency (TDF) and Time scale-Magnitude-Frequency (TMF) relationships, respectively. The theoretical distributions were tested for duration

Intensity-DurationFrequency and spatial analysis of droughts

M. Mohseni Saravi et al.

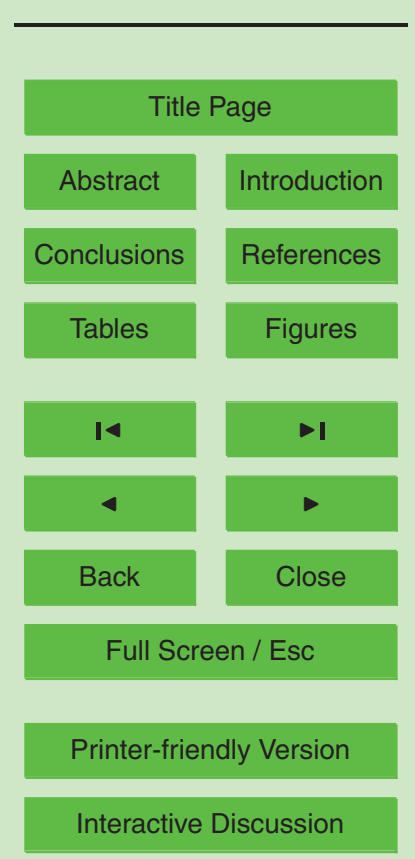


and their magnitude series. The results of the Mean Relative Deviation test at $95 \%$ confidence level for theoretical frequency distribution fitting are shown in Table 3 for the different time scales. Using suitable frequency distributions, drought durations and magnitudes were computed, corresponding to 5, 10, 20, 50 and 100-year return pe5 riods. The calculated values were applied to develop TDF and TMF relationships for the mentioned return periods, and the corresponding diagrams are produced for each station.

\subsection{Spatial extent of droughts}

The SPI characteristics presented in Table 1 were used to generate drought maps for the Karoon basin using GIS. An Inverse Distance Weighting with Power (IDW) methodology was used for interpolation of the station data. The output grid cell size, the number of neighborhoods and the power for distance parameter was estimated by trial and error. In order to provide a more quantitative basis for comparison of the estimated and observed values, RMS error was calculated. Considering the characteristics mentioned in Table 2, several drought maps were plotted for each time scale:

I) Drought maps through the end of May 1999

In 1999, a severe drought affected most areas of the Iran plateau. In order to assessing SPI values across Karoon basin and occurrence of this event, drought maps through the end of May 1999, an important month for agriculture, were developed. Figures 7 , 8 and 9 show the spatial distribution of SPI through the end of May 1999 for the 3-, 6and 12-month time scales, respectively. Classification system shown in Table 1 was used to define drought intensities based on the SPI.

\section{II) Iso-frequency drought maps}

The relative frequencies (RF) presented in Table 3 (excluding the 3- and 6-month SPI)

were used to develop iso-frequency drought maps over the Karoon basin (Figs. 10 and
HESSD

$6,1347-1383,2009$

Intensity-Duration-

Frequency and spatial analysis of droughts

M. Mohseni Saravi et al.

Title Page

Abstract

Introduction

Conclusions

Tables

References

Figures

14

$\rightarrow$

4

Back

Close

Full Screen / Esc

Printer-friendly Version

Interactive Discussion 
11). These values were computed by Eq. (2).

$R F=\frac{n}{N} \times 100$

HESSD

$n:$ number of months with drought evens (Negative SPI)

$N$ : number of total months

$5 \quad$ III) Iso-duration drought maps

The longest drought duration at each station presented in Table 3 were used to develop iso-duration maps over the Karoon basin (Figs. 12 and 13). Longest drought duration is expressed in terms of the maximum number of consecutive days of no rain for each station. For example the longest drought duration is 27 month from 1988 to 1991 at 10 Abadan (AB) station.

IV) Iso-intensity drought maps

The observed peak intensities (during the 1972-1999 periods) presented in Table 3 were used to develop iso-intensity drought maps over the Karoon basin (Figs. 14 and 15). The peak drought intensity is the highest departure of the index from its normal value at each station. For example the peak drought intensity is -2.71 in March 1989 at Abadan $(A B)$ station.

\section{V) Development of TDF and TMF drought maps}

In considering different return periods for drought, along with their duration and magnitude (corresponding to three time scales), at least 30 drought maps can be developed 20 for the basin. Figures 16 and 17 show drought maps of the magnitude and duration of a five-year drought based on the 12-month SPI, respectively.

Intensity-DurationFrequency and spatial analysis of droughts

M. Mohseni Saravi et al.

Title Page

Abstract Introduction

Conclusions References

Tables Figures

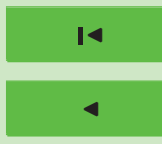

$>$ I

Back

Close

Full Screen / Esc

Printer-friendly Version

Interactive Discussion 


\section{Results}

\subsection{Historical analysis of droughts}

As said before, calculating the SPI for a specific time scale at any location requires a good fit of a Gamma frequency distribution to the precipitation data. Application of the 5 Mean Relative Deviation test at $95 \%$ confidence level indicates that the Gamma distribution provides a reasonable and acceptable approximation of the frequency of rainfall values. Furthermore, these results are consistent with JAMAB (Water Resources Development, Consulting Engineers of Iran) findings (1999). Thus we believe that the SPI can be used effectively for analyzing drought in this basin (Fig. 3).

The 3-, 6-, and 12-month SPI values for Yasooj station are shown in Fig. 4 for the 1972-1999 periods. As one can see, a drought's characteristics change with time. At longer time scales, droughts become less frequent but their duration increases.

Three-month SPI time series computed for Yasooj show significant droughts in 1973, the middle and late 1980s, 1993 and 1999. The 1984-1985 and 1999 droughts were 15 very severe and had a substantial impact on the region. Based on 3-month SPI values, the longest droughts at Yasooj lasted 13 months on two occasions, from October 1983 to October 1984, and from August 1988 to August 1989. However, the drought of 1998-1999, with a peak intensity (PI) of -3.08 (extreme drought) and a mean intensity (MI) of -1.64 , had a greater impact on the area. The peak intensity occurred in June 201999 and the relative frequency of droughts during this time frame was approximately $50 \%$.

Based on 6-month SPI, several droughts were identified during 1972-1999. Among these droughts, the droughts of 1983-1984, 1987-1989 and 1999 were the most significant. The longest duration drought, which began in 1987 and withdrew in 1989, 25 lasted twenty four months. The drought of 1999, lasting sixteen months, had a peak intensity of -2.97 (extreme drought) and a mean intensity of -1.64 , which fell into a severe classification. The SPI peak intensity $(-2.97)$ of this time scale occurred in August 1999 and the relative frequency of droughts of this time scale was approximately
HESSD

$6,1347-1383,2009$

Intensity-Duration-

Frequency and spatial analysis of droughts

M. Mohseni Saravi et al.

Title Page

Abstract

Introduction

Conclusions

Tables

References

Figures

14

4

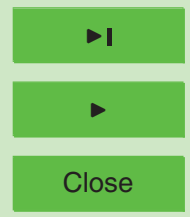

Full Screen / Esc

Printer-friendly Version

Interactive Discussion 
$49.5 \%$.

Analysis of the 12-month SPI indicates that four significant drought periods occurred in the years 1983-1985, 1987-1990, 1992-1993 and 1998-1999. The longest droughts at Yasooj lasted 26 months between October 1983 and November 1985, and 5 again from November 1987 to February 1990. The drought of 1998-1999, with a peak intensity of -2.26 (extreme drought) and a mean intensity of -1.25 had the greatest impact on the area. The relative frequency of droughts during this period was approximately $46.1 \%$. The peak intensity during $1972-1999$ periods was -2.97 , which occurred in November 1999.

10 Table 2 summarizes drought characteristics from 1972-1999 for the stations across the basin based on a 12-month time scale. Similar characteristics are obtained for 3- and 6-month time scales (data are not shown). As shown in Table 3, almost all stations have experienced peak intensities of less than -2 , falling into an extreme classification. Stations with peak intensities of less than -3 are noticeable. Most of these peak intensities occurred in the 1990s, especially during 1999. The greatest intensity ( $\mathrm{SPI}=-4.02)$ occurred in January 1985 at Menj (MJ).

The longest drought lasted 79 months from April 1980 to October 1986 at Darshahi (DA). The peak intensity of this drought was -1.94 , its magnitude was -61 , and its mean intensity was -0.77 . The 71 -month drought at Shahmokhtar (SM) with a magnitude of -55 and mean intensity of -0.78 also stands out. The drought of 1998-1999 with a duration of 13 months, a magnitude of -28.2 and mean intensity of -2.17 at Batari (BT) had a greater impact on the area in comparison to the previously mentioned droughts. As shown in Table 3, almost all stations experienced their longest and most and intense droughts during the 1980s.

The relative frequencies of Darshahi (DA), Shahmokhtar (SM), Harmaleh (HR) and Chamzaman $(\mathrm{CH})(57.8 \%, 56.9 \%, 55.7 \%$, and $57.2 \%$, respectively) are more noticeable than others.

\section{HESSD}

$6,1347-1383,2009$

Intensity-Duration-

Frequency and spatial analysis of droughts

M. Mohseni Saravi et al.

Title Page

Abstract

Introduction

Conclusions

Tables

References

Figures

14

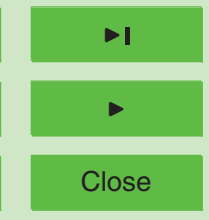

Full Screen / Esc

Printer-friendly Version

Interactive Discussion 
3.2 Results of TDF and TMF drought analysis

As already mentioned, the theoretical distributions were tested for duration and magnitude series. The results of the Mean Relative Deviation test at 95\% confidence level for theoretical frequency distribution fitting are shown in Table 3 for the different time 5 scales.

Figures 5 and 6 show the TDF and TMF diagram relationships developed for Abadan $(A B)$, in which each curve corresponds to a different time scale.

TDF and TMF curves show that correspond to increasing return periods and time scales increasing durations and magnitudes. In other words, greater durations and

\subsection{Spatial extent of droughts}

As said before, the SPI characteristics presented in Table 3 were used to generate drought maps for the Karoon basin using IDW methodology for interpolation of the station data in GIS software. The results of trail and error and RMS error suggested $5500 \times 500 \mathrm{~m}^{2}$ for output cell size, 12 neighborhoods, and 2 for the power of distance parameter.

\section{I) Drought maps through the end of May 1999}

SPI values in all stations across the Karoon basin clearly indicated the occurrence of a severe drought in 1999. The 3-month SPI map (Fig. 7) through the end of May 1999 shows that most of the region is characterized by severe drought conditions. The area influenced by each category (near-normal, moderate dryness, severe dryness and extreme dryness) are $9.5 \%, 15.9 \%, 45 \%$ and $29.1 \%$, respectively. There is an increasing gradient in drought intensities from the center of the basin to the west and southeast. In other words, the southeastern and western parts experienced an extreme
HESSD

6, 1347-1383, 2009

Intensity-Duration-

Frequency and spatial analysis of droughts

M. Mohseni Saravi et al.

Title Page

Abstract

Introduction

Conclusions

References

Tables

Figures

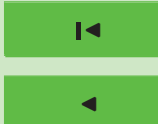

$\rightarrow 1$

Back

Close

Full Screen / Esc

Printer-friendly Version

Interactive Discussion 
Also, the 6-month SPI map (Fig. 8) through the end of May 1999 reflects the severe droughts in the southeast, center and west. The influenced areas by each abovementioned category are $11.3 \%, 38.8 \%, 46 \%$ and $4 \%$, respectively.

The 12-month SPI map (Fig. 9) through the end of May 1999, indicates that most of 5 the basin had experienced severe droughts too. The influenced areas by the mentioned classifications (near-normal, moderate dryness, severe dryness and extreme dryness) are $7.2 \%, 23.4 \%, 62 \%$ and $7.5 \%$, respectively. As the 3- and 6-month SPI maps, the 12-month SPI map show a severe and extreme dryness condition in the southeast, center and western parts of the basin too. The southwest and outlets had experienced near normal and moderate dryness in all timescales.

II) Iso-frequency drought maps

The iso-frequency drought map of the 3-month SPI (Fig. 10) shows that the northeastern and southeastern regions are characterized as being in drought more frequently than other regions. The central region and watershed outlets have lower relative frequencies. Drought frequencies decrease from northern parts to the outlet of the basin. The iso-frequency drought map of the 12-month SPI (Fig. 11) shows that the southeastern, western and northern parts of the basin have experienced drought more frequently than the central parts and outlets. The variation of frequency values is very low for the two time scales, but the 12-month SPI has greater frequencies than the 3-month SPI overall.

\section{III) Iso-duration drought maps}

The 3-month SPI iso-duration map (Fig. 12) indicates that the northern, northeastern and southeastern regions have experienced droughts of greater duration when compared to the western and outlet parts of the basin. However, most of the basin has experienced high durations, decreasing from the north, northeast and southeast towards the outlet.

As expected, drought durations detected by the 12-month SPI were greater than those of the 3-month SPI. The iso-duration map of the 12-month SPI (Fig. 13) shows 1358

HESSD

$6,1347-1383,2009$

Intensity-Duration-

Frequency and spatial analysis of droughts

M. Mohseni Saravi et al.

Title Page

Abstract

Introduction

Conclusions

Tables

References

Figures

14

4

$\rightarrow 1$

Back

$>$

Close

Full Screen / Esc

Printer-friendly Version

Interactive Discussion 
greater durations in the southeastern, northern and western regions than those of the center and outlets.

HESSD

\section{IV) Iso-Intensity drought maps}

The 3-month iso-intensity drought map (Fig. 14) shows greater intensities in south5 eastern and western parts than the outlet, central and northern regions. In this map, there are more high intensity affected areas than there are areas of lower intensity. The 12-month iso-intensity drought map (Fig. 15) indicates that southeastern and central parts of the basin have experienced greater intensities than those of the west, north and outlets during the study period. Although the intensity values at this time scale are higher than the 3-month SPI, the affected area is smaller.

\section{V) Development of TDF and TMF drought maps}

The 12-month SPI drought magnitude map for a five-year return period shows an increasing trend in drought magnitude from the center to the western and southeastern parts of the Karoon basin. The highest magnitudes correspond to the western parts. This map (Fig. 16) identifies that most of the area experiences high magnitude droughts during a five-year return period. The 12-month SPI iso-duration map for a five-year return period (Fig. 17) indicates that the southeastern, northern and central regions experience longer durations than other parts of the basin.

\section{Discussion and conclusions}

20 The SPI values for all of the stations and drought maps for May 1999 clearly indicate that a significant drought occurred across the basin (Figs. 7, 8 and 9). The areas assigned to moderate and severe drought classes based on the 3- and 12-month SPI highlight the fact that very little precipitation fell over the majority of the area during 1998-1999. In 1999, the average rainfall over the country was only $132 \mathrm{~mm}$, which is 25 a reduction of about $25 \%$ and $41 \%$ in comparison to the average of the previous year
6, 1347-1383, 2009

Intensity-DurationFrequency and spatial analysis of droughts

M. Mohseni Saravi et al.

\section{Title Page}

Abstract Introduction

Conclusions

Tables References Figures

14

4

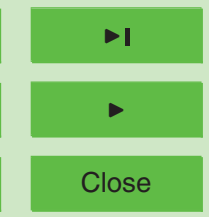

Full Screen / Esc

Printer-friendly Version

Interactive Discussion 
(1998) and the average of the previous 31 years, respectively (Khazaee, 2002). This extreme drought actually began late in 1998. In 1998, the average precipitation deficit was $41 \%$, in comparison to 1997 (Maleki Nezhad, 1999). These results of this study confirm the findings of Faraj Zadeh (1999) and Ghatreh Samani (1999).

5 The extreme drought of 1999 had a great impact across the region, especially in the southeast near Yasooj (YS), Dahshahi (DA), and Batari (BT). Different sectors were influenced by drought conditions such as: agriculture, energy, environmental and social. Farmers were concerned about the lack of rainfall and its impact on the winter wheat crop. The precipitation deficit decreased pasture production by approximately $1050 \%$ (Shafiee et al., 1999). The SPI analysis conducted here demonstrates that this index would have been a beneficial tool for detecting and monitoring the drought of 1999.

The relative frequencies reflect the answer of this question: "How many droughts have occurred in the past in the Karoon basin?" The results show that the mean relative 15 frequencies of $40.16 \%$ and $50.45 \%$ for drought occurring in the Karoon basin at 3 and 12 month timescales. 3 and 12 month iso-frequency drought maps reflect the shortterm and long-term water deficit over the basin, respectively. As shown in Figs. 10 and 11 long-term water resources have been affected in the western and northern parts. In the southeast and north, however, short-term water supplies have been influenced.

20 A drought with the longest duration is not necessarily the most intense, so it may not result in the largest impacts or damages. Factors such as the onset or the mean intensity must also be looked at in addition to the magnitude and peak intensity (McKee et al., 1995). For example, the longest 12-month SPI drought at Batari (BT), which lasted for 37 months with a Magnitude of -25.3 and a Mean Intensity (MI) of -0.68 , 25 had less impacts than the 13 month drought (December 1998 to December 1999) with a magnitude of -28.2 and Mean Intensity of -2.17 (Table 3 ).

The 12-month SPI iso-duration map of the Karoon basin shows greater durations than those based on the 3-month SPI. In the 12-month Iso-duration map, most of the area experienced lower durations in comparison with the 3-month Iso-duration map.

\section{Intensity-Duration- Frequency and spatial analysis of droughts}

M. Mohseni Saravi et al.

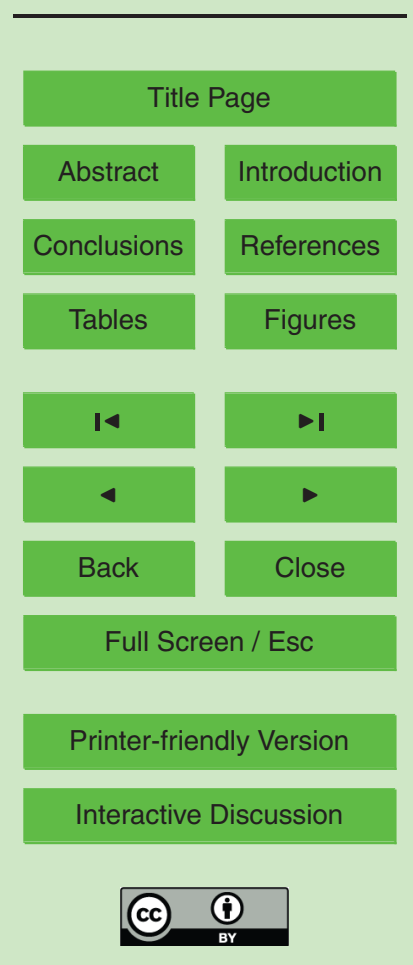


This indicates that short-term water supplies were affected more than long-term water resources (Figs. 12 and 13).

The observed Peak Intensities of SPI values during 1972-1999 illustrate some extreme droughts $(\mathrm{SPI}<-2)$ across the basin (Table 3$)$. These extreme droughts occur

5 approximately only two or three times in 100 years, and are valuable tools for water resources managers interested in either short- or long- term or water supply. The iso-intensity drought maps (Figs. 14 and 15) show that the southeastern region of the basin, near Pataveh, Darshahi, Batari and Yasooj, has experienced greater peak intensities than other parts of the Karoon basin during the 1972-1999 periods.

10 The development of TDF and TMF curves over the Karoon basin is important for contemporary hydro-climate and agro-climate design and planning of the basin. The TDF and TMF curves appear to be as expected, since for increasing return periods and time scales there is a corresponding increase in the magnitude and durations of the droughts. At this point, it should be mentioned that the low frequency events, i.e. 15 events with return periods of 50 and 100 years, have much more uncertainty than more frequent events. The reason for this implication is due to an insufficient record period of data that leads an extrapolation of the fitted theoretical frequency distribution for extreme events. However, since the sample of recorded data used in this study is reasonably long (28 years), the uncertainty of extreme events is not high.

20 Finally, our findings show that extreme drought conditions are more prevalent in the southeastern part of the basin near Pataveh (PT), Darshahi (DA), Batari (BT) and Yasooj (YS) stations. Thus, this area is potentially more sensitive or vulnerable to droughts than any other part of the Karoon basin.

\section{References}

Bazrafshan, J. and Khalili, A.: A comparative study of several meteorological drought indices in some climate zones of Iran, Master's Thesis, University of Tehran, Iran, 256 pp., 2000 (in Persian).

HESSD

6, 1347-1383, 2009

Intensity-DurationFrequency and spatial analysis of droughts

M. Mohseni Saravi et al.

\section{Title Page}

Abstract Introduction

Conclusions

Tables References Figures

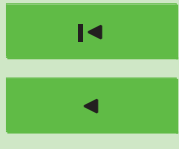
$>1$

Back

Close

Full Screen / Esc

Printer-friendly Version

Interactive Discussion 
Bordi, I., Fragio, S., Parenti, P., Speranza, A., and Sutera, A.: The Analysis of the Standardized Precipitation Index in the Mediterranean area: Part 1., J. of the Annali Di Geofisica, 44(5-6), 979-993, 2001.

Dalezios, R. N., Loukas, A., Vasiliades, L., and Liakapoulos, E.: Severity-Duration-Frequency analysis of droughts and wet periods in Greece, Hydrol. Sci. J., 45(5), 751-769, 2000.

Dracup, J. A., Lee, K. S., and Paulson, E. G.: On the definition of droughts, Water Resour. Res., 16(2), 297-302, 1980.

Dupigny, G. and Lesley, A.: Towards characterizing and planning for drought in Vermont-Part 1: A climatological perspective, J. Am. Water Resour. As., 37(3), 505-524, 2001.

10 Edwards, D. C.: Characteristics of 20th century drought in the United States at multiple time scales, MSc Thesis, Colorado State University, 155 pp., 1997.

Faraj Zadeh, M., Movahed Danesh, A., and Ghaemi, H.: Drought in Iran (Application of some indices), Journal of Danesh-Keshavarzi, 1(2-5), 31-51, 2001 (in Persian).

Ghatreh Samani, S.: Analysis of drought trend in Chaharmahal-o-Bakhtiari province, Proceed15 ings of First National Conference on Drought Mitigation and Water Shortage, 27-28 February, 121-127, Kerman, 2001 (in Persian).

Guttman, B. N.: Comparing the Palmer Drought Index and the Standardized Precipitation Index, J. Am. Water Resour. As., 34(1), 113-121, 1999.

Hayes, M., Svoboda, J., Wilhite, D., and Vanyarkho, A.: Monitoring the 1996 Drought Using the Standardized Precipitation Index, B. Am. Meteorol. Soc., 80(3), 429-438, 1999.

Hayes, M.: Drought Indices, National Drought Mitigation Center, http://www.drought.unl.edu/ whatis/indices.htm, 2000.

Water Resources Development Annual Report, Consulting Engineers of Iran, 230 pp., 1999 (JAMAB, in Persian).

Kashkoli, H. A. and Hoseini Zaree, N.: The long-term effects of new irrigation plantings on water quality of Karoon River, Proceeding of first national conference on drought mitigation and water shortage, 27-28 February, Kerman, Iran, 917-925, 2001 (in Persian).

Khazaee, M. R.: Drought severity forecasting and low flow; case study: Kermanshah provinceGharehsoo river, Master's thesis, University of Science and Industry of Iran, 2001 (in Persian).

Maleki Nezhad, $\mathrm{H}$.: Analysis of deficit irrigation technique, groundwater irrigation and its influence on reduction of drought damages, Proceedings of first national conference on drought mitigation and water shortagem 27-28 February, Kerman, Iran, 793-799, 2001 (in Persian).

HESSD

$6,1347-1383,2009$

\section{Intensity-Duration- Frequency and spatial analysis of droughts}

M. Mohseni Saravi et al.

Title Page

Abstract

Introduction

Conclusions

References

Tables

Figures

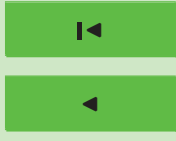

$\rightarrow$

Back

Close

Full Screen / Esc

Printer-friendly Version

Interactive Discussion 
Mahdavi, M.: Applied Hydrology, Tehran University Publication, Tehran, Iran, 1998 (in Persian).

McKee, B. T., Nolan, J., Doesken, N. J., and Kleist, J.: Droght monitoring with multiple timescales, 9th Conference on Applied Climatology, 15-20 January, Boston, Massachusetts, USA, 233-236, 1995.

5 McKee, B. T., Nolan, J., Doesken N. J., and Kleist, J.: The relationship of drought frequency and duration to tomescales, 8th Conference on Applied Climatology, 17-22 January, Anaheim, CA, USA, 179-184, 1993.

Palmer, W. C.: Meteorological drought, Research paper no. 45, US weather bureau, Washington, DC, USA, 1995.

10 Shafiee, A. and Mehrabi, M: The effect of drought on forest and rangeland ecosystems at Kohkiloee and Boeer Ahmad Province and its mitigation solutions, Proceeding of first national conference on drought mitigation and water shortage, 27-28 February, Kerman, Iran, 742749, 2001 (in Persian).

Thompson, S.: Hydrology for water management, A. A. Balkema Publication, Rotterdam, The Netherlands, 476 pp., 1999.

Wilhite, D. A. and Glantz, M. H.: Understanding the drought phenomenon: the role of definitions, Water Int., 10, 111-120, 1985.

Wilhite, D. A.: Drought: A Global Assessment, Natural Hazards and Disasters Series, Routledge Publishers, 752 pp., London, UK, 2000.

\section{HESSD}

$6,1347-1383,2009$

\section{Intensity-Duration- Frequency and spatial analysis of droughts}

M. Mohseni Saravi et al.

\section{Title Page}

Abstract

Introduction

Conclusions

References

Tables

Figures

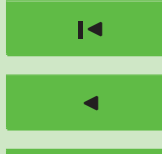

$\rightarrow$

Back

Close

Full Screen / Esc

Printer-friendly Version

Interactive Discussion 


\section{HESSD}

$6,1347-1383,2009$

\section{Intensity-Duration- \\ Frequency and spatial analysis of droughts}

Table 1. Classification of drought intensities based on SPI.

\begin{tabular}{ll}
\hline SPI & Drought category \\
\hline$>+2$ & Extremely wet \\
1.99 to 1.5 & Very wet \\
1.49 to 1.0 & Moderately wet \\
0.99 to -0.99 & Near normal \\
-1 to -1.49 & Moderate dryness \\
-1.5 to -1.99 & Severe dryness \\
$<-2$ & Extreme dryness \\
\hline
\end{tabular}

M. Mohseni Saravi et al.

Title Page

Abstract

Introduction

Conclusions

References

Tables

Figures

14

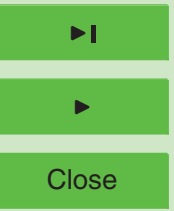

Back

Full Screen / Esc

Printer-friendly Version

Interactive Discussion 


\section{HESSD}

Table 2. Drought characteristics of 12-month time scales for the stations used in this study.

\begin{tabular}{|c|c|c|c|c|c|c|c|c|c|c|c|c|c|}
\hline \multirow[t]{2}{*}{ Station name } & \multirow[t]{2}{*}{ Station code } & \multicolumn{3}{|c|}{$\begin{array}{l}\text { Observed peak intensity } \\
\text { during } 1972-1999\end{array}$} & \multicolumn{4}{|c|}{ Longest duration } & \multicolumn{4}{|c|}{ Most intense duration } & \multirow[t]{2}{*}{$R F \%$} \\
\hline & & SPI & year & month & $D(m o)$ & Years & $M$ & MI & $D(m o)$ & Years & $M$ & $M I$ & \\
\hline Abadan & $A B$ & -2.71 & 1989 & Mar & 27 & $88-91$ & -36.4 & -1.35 & 27 & $88-91$ & -36.36 & -1.35 & 47.7 \\
\hline Ahwaz & $\mathrm{AH}$ & -2.7 & 1995 & Nov & 25 & $78-80$ & -15.2 & -0.61 & 15 & $88-89$ & -20.1 & -1.34 & 49.2 \\
\hline Brojen & BR & -3.3 & 1977 & Nov & 34 & $76-79$ & -56.1 & -1.65 & 34 & $76-79$ & -56.1 & -1.65 & 43.7 \\
\hline Menj & MJ & -4.02 & 1985 & Jan & 25 & $83-85$ & -49.7 & -1.99 & 25 & $83-85$ & -49.74 & -1.99 & 46.8 \\
\hline Sad Dez & SD & -2.54 & 1999 & Nov & 38 & $82-83$ & -35.5 & -0.93 & 38 & $82-85$ & -35.47 & -0.93 & 48.0 \\
\hline Yasooj & YS & -2.47 & 1999 & Nov & 26 & $83-85$ & -32.4 & -1.25 & 26 & $83-85$ & -32.4 & -1.25 & 46.2 \\
\hline Shah Mokhtar & SM & -2.38 & 1999 & Nov & 71 & $80-86$ & -55 & -0.78 & 71 & $80-86$ & -55.04 & -0.78 & 56.9 \\
\hline Darshahi & DA & -2.61 & 1999 & Nov & 79 & $80-86$ & -61 & -0.77 & 79 & $80-86$ & -60.99 & -0.77 & 57.8 \\
\hline Batari & BT & -3.2 & 1999 & Nov & 37 & $83-86$ & -25.3 & -0.68 & 13 & $98-99$ & -28.2 & -2.17 & 50.2 \\
\hline Pataveh & PT & -2.4 & 1999 & Nov & 48 & $81-85$ & -42.1 & -0.88 & 48 & $81-85$ & -42.06 & -0.88 & 46.5 \\
\hline Morghak & MR & -2.61 & 1996 & Dec & 48 & $96-99$ & -64.8 & -1.35 & 48 & $96-99$ & -64.8 & -1.35 & 53.5 \\
\hline Pol Shalo & PS & -2.2 & 1996 & Dec & 28 & $83-85$ & -21.8 & -0.78 & 14 & $98-99$ & -23.18 & -1.66 & 51.7 \\
\hline Godarland & GD & -3.27 & 1989 & Dec & 46 & $96-99$ & -51.7 & -1.12 & 46 & $96-99$ & -51.69 & -1.12 & 49.5 \\
\hline Batvand & BV & -1.96 & 1980 & Dec & 34 & $76-79$ & -32 & -0.94 & 34 & $76-79$ & -32.03 & -0.94 & 55.1 \\
\hline Chamzaman & $\mathrm{CH}$ & -2.09 & 1990 & Dec & 49 & $95-96$ & -56.5 & -1.15 & 49 & $95-99$ & -56.45 & -1.15 & 57.2 \\
\hline Tale Zang & $\mathrm{TZ}$ & -2.24 & 1996 & Dec & 47 & $82-85$ & -28.5 & -0.61 & 31 & 88-91 & -23.34 & -0.75 & 53.2 \\
\hline Harmaleh & $\mathrm{HR}$ & -2.41 & 1994 & Jan & 39 & $81-85$ & -28.2 & -0.72 & 39 & $81-85$ & -28.22 & -0.72 & 55.7 \\
\hline Molasani & MO & -2.33 & 1994 & Jan & 25 & $80-82$ & -10 & -0.4 & 15 & $83-85$ & -19.86 & -1.32 & 47.5 \\
\hline Darkhoin & DK & -2.3 & 1994 & Jan & 29 & $82-85$ & -30 & -1.03 & 29 & $82-85$ & -29.95 & -1.03 & 47.1 \\
\hline Haft Tapeh & HT & -2.27 & 1984 & Oct & 37 & $83-86$ & -40.4 & -1.09 & 37 & $83-86$ & -40.44 & -1.09 & 51.7 \\
\hline Hemgin & $\mathrm{HG}$ & -2.28 & 1986 & Jan & 48 & $94-98$ & -42.8 & -0.89 & 48 & $94-98$ & -42.83 & -0.89 & 52.3 \\
\hline Share Kord & SK & -2.2 & 1984 & Jan & 31 & $83-86$ & -33.2 & -1.07 & 31 & $83-86$ & -33.18 & -1.07 & 50.8 \\
\hline Shams Abad & SA & -2.76 & 1999 & Oct & 31 & $83-86$ & -17.3 & -0.56 & 28 & $90-92$ & -35.72 & -1.28 & 50.7 \\
\hline Khoram Abad & $\mathrm{KA}$ & -2.5 & 1973 & Dec & 25 & $82-84$ & -31.7 & -1.27 & 25 & $82-84$ & -31.65 & -1.27 & 45.8 \\
\hline Najaf Abad & NA & -2.36 & 1973 & Dec & 23 & $81-82$ & -23.6 & -1.02 & 17 & $88-89$ & -25.9 & -1.52 & 45.5 \\
\hline Damane Faridan & DF & -2.2 & 1973 & Dec & 31 & $83-86$ & -28.6 & -0.92 & 31 & $83-86$ & -28.58 & -0.92 & 49.5 \\
\hline Emam Gheis & EG & -2.48 & 1986 & Jan & 34 & $73-75$ & -30.1 & -0.88 & 30 & $83-86$ & -33.93 & -1.13 & 52.3 \\
\hline Hamidiee & $\mathrm{HA}$ & -2.5 & 1973 & Dec & 47 & $93-97$ & -44 & -0.94 & 47 & $93-97$ & -44 & -0.94 & 49.5 \\
\hline Dehkadeh Shahid & DS & -1.99 & 1985 & Feb & 28 & $80-83$ & -19.8 & -0.71 & 23 & $88-89$ & -24.79 & -1.08 & 51.7 \\
\hline
\end{tabular}

$6,1347-1383,2009$

\section{Intensity-Duration- Frequency and spatial analysis of droughts}

M. Mohseni Saravi et al.

$P I$ : peak intensity, $D(m o)$ : Duration (month), $M$ : Magnitude, $M I$ : Mean Intensity, $R F$ : Relative Frequency

Title Page

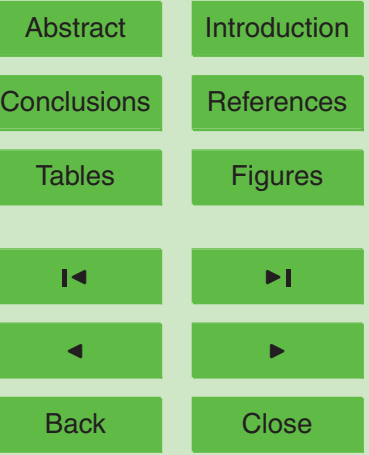

Full Screen / Esc 


\section{HESSD}

$6,1347-1383,2009$

\section{Intensity-Duration- \\ Frequency and spatial analysis of droughts}

M. Mohseni Saravi et al.

Table 3. Probability distributions fitted to the duration and magnitude values.

\begin{tabular}{lll}
\hline Time scale & Durations series & Magnitude series \\
\hline SPI-3 & 3 parameters Log - Normal & Log Pearson \\
SPI-6 & 2 parameters Gamma & Log Pearson \\
SPI-12 & Log Pearson & Log Pearson \\
\hline
\end{tabular}

Title Page

Abstract

Introduction

Conclusions

References

Tables

Figures

14

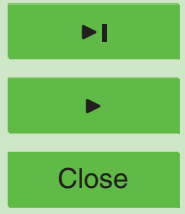

Back

Full Screen / Esc

Printer-friendly Version

Interactive Discussion 


\section{HESSD}

$6,1347-1383,2009$

\section{Intensity-Duration- \\ Frequency and \\ spatial analysis of droughts}

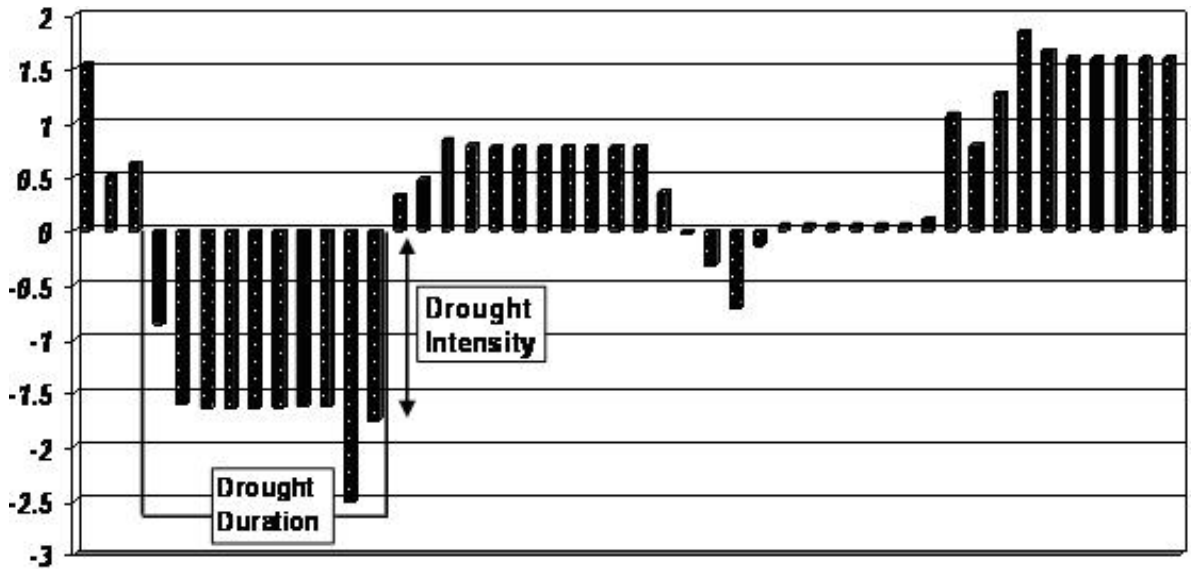

M. Mohseni Saravi et al.

Title Page

Abstract

Introduction

Conclusions

References

Tables

Figures

14

$>$ I

Fig. 1. A Schematic view of drought intensity and duration.

4

Back

Close

Full Screen / Esc

Printer-friendly Version

Interactive Discussion 


\section{HESSD}

6, 1347-1383, 2009

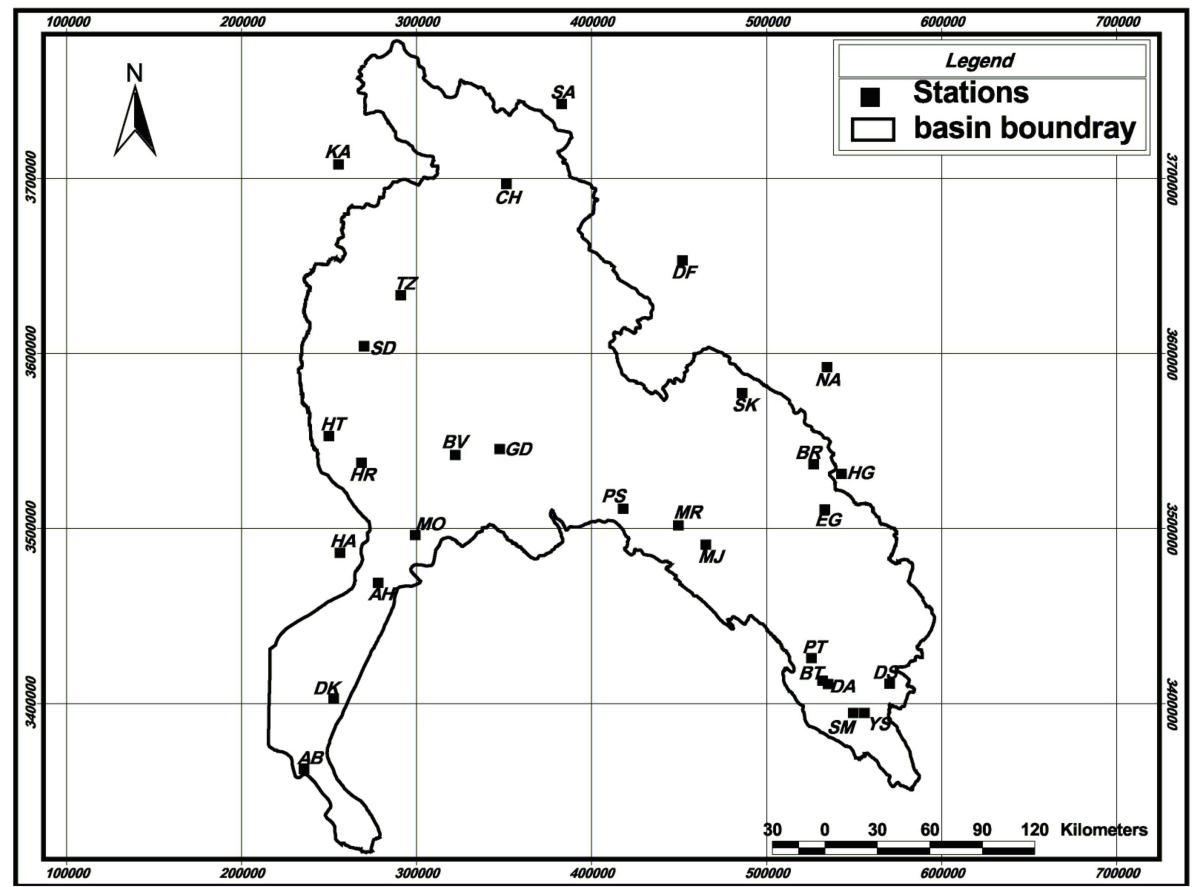

\section{Intensity-Duration- \\ Frequency and \\ spatial analysis of droughts}

M. Mohseni Saravi et al.

\section{Title Page}

Abstract

Introduction

Conclusions

References

Tables

Figures

14

- I

4

Back

Close

Full Screen / Esc

Fig. 2. Map of the study basin with the selected stations.

Printer-friendly Version

Interactive Discussion 


\section{HESSD}

6, 1347-1383, 2009

\section{Intensity-Duration- \\ Frequency and \\ spatial analysis of droughts}

M. Mohseni Saravi et al.

\section{Title Page}

Abstract

Introduction

Conclusions

References

0.1

0.0

$\begin{array}{lllllll}50 & 100 & 150 & 200 & 250 & 300 & 350\end{array}$

Abadan station12 month (Junuary-

December)precipitation( $\mathrm{mm}$ ) expcted observed

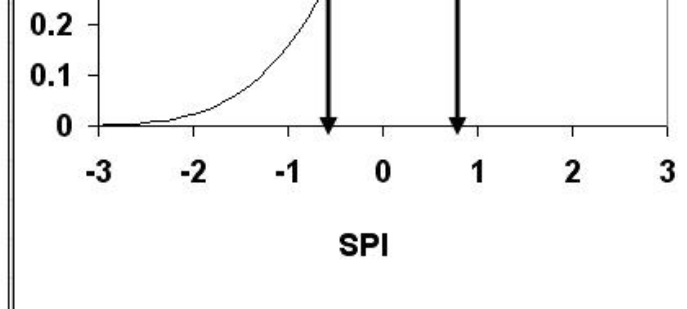

Fig. 3. Gamma frequency distribution fitting to the precipitation data and SPI calculation.
Tables

Figures

14

4

Back

Full Screen / Esc

Printer-friendly Version

Interactive Discussion 


\section{HESSD}

SPI-3

\section{6, 1347-1383, 2009}

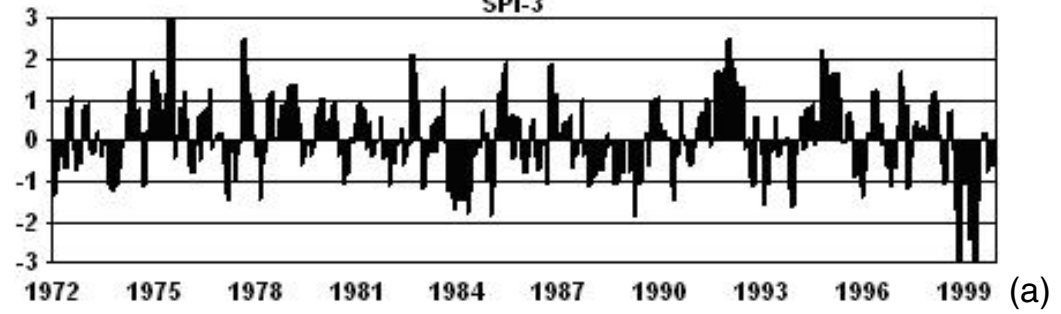

Intensity-Duration-

Frequency and spatial analysis of droughts

M. Mohseni Saravi et al.

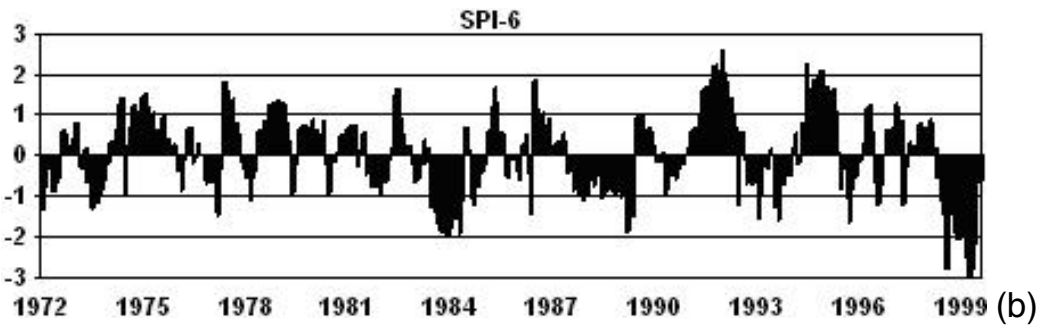

SPI-12

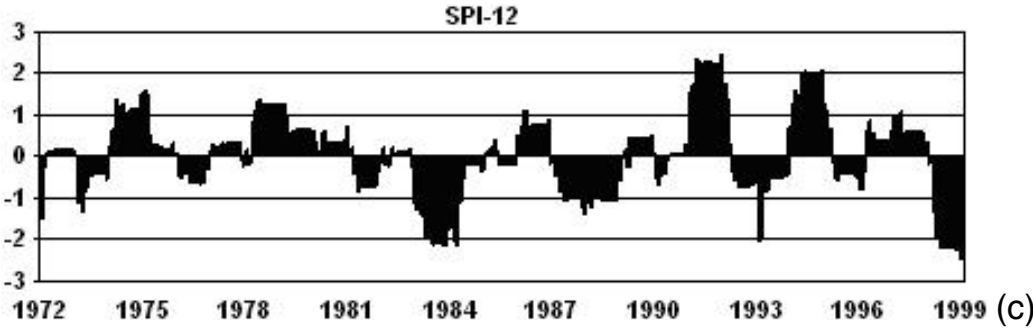

Title Page

Abstract

Introduction

Conclusions

References

Tables

Figures

14

$\rightarrow$

4

Back

Close

\section{Full Screen / Esc}

Fig. 4. Standardized Precipitation Index time series calculated for Yasooj station, 1972-1999 for 3-, 6- and 12-month time scales.

Printer-friendly Version

Interactive Discussion 


\section{HESSD}

$6,1347-1383,2009$

\section{Intensity-Duration- \\ Frequency and spatial analysis of droughts}

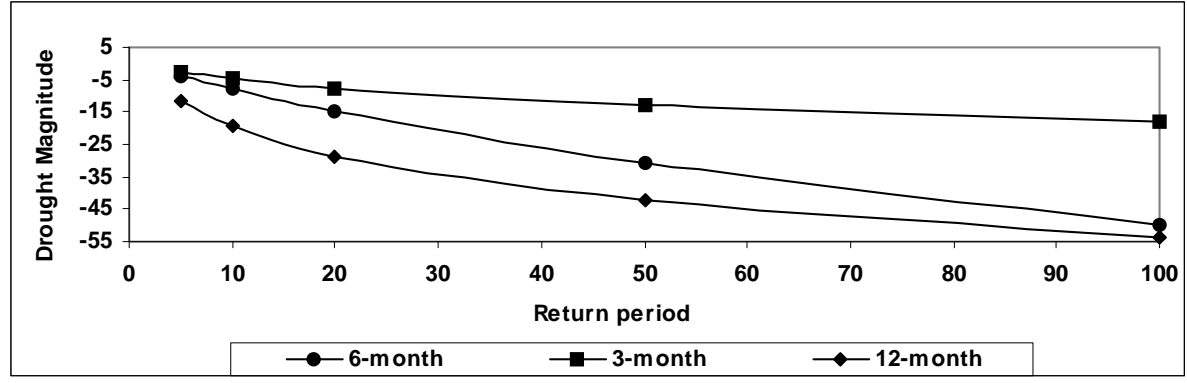

M. Mohseni Saravi et al.

Title Page

Abstract

Introduction

Conclusions

References

Tables

Figures

Fig. 5. Time scale-Magnitude-Frequency curves of different return periods (in years) for Abadan station $(A B)$.

\section{4}

4

Back

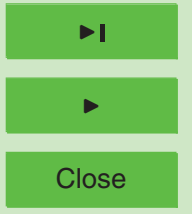

Full Screen / Esc

Printer-friendly Version 


\section{HESSD}

$6,1347-1383,2009$

\section{Intensity-Duration- \\ Frequency and spatial analysis of droughts}

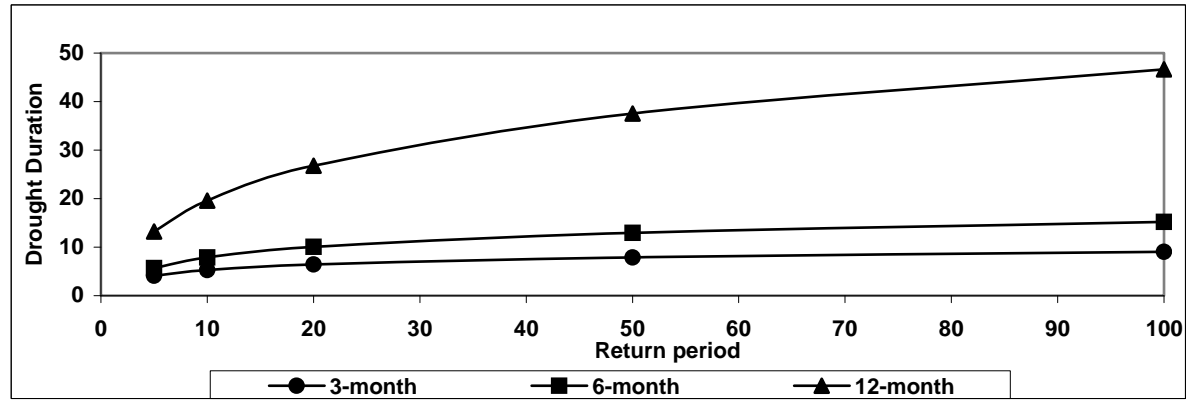

M. Mohseni Saravi et al.

Title Page

Abstract

Introduction

Conclusions

References

Tables

Figures

Fig. 6. Time scale-Duration-Frequency curves of different return periods (in years) for Abadan station $(A B)$.

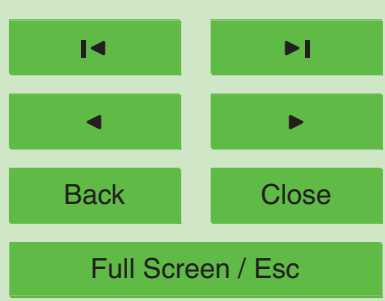

Printer-friendly Version

Interactive Discussion 


\section{HESSD}

6, 1347-1383, 2009

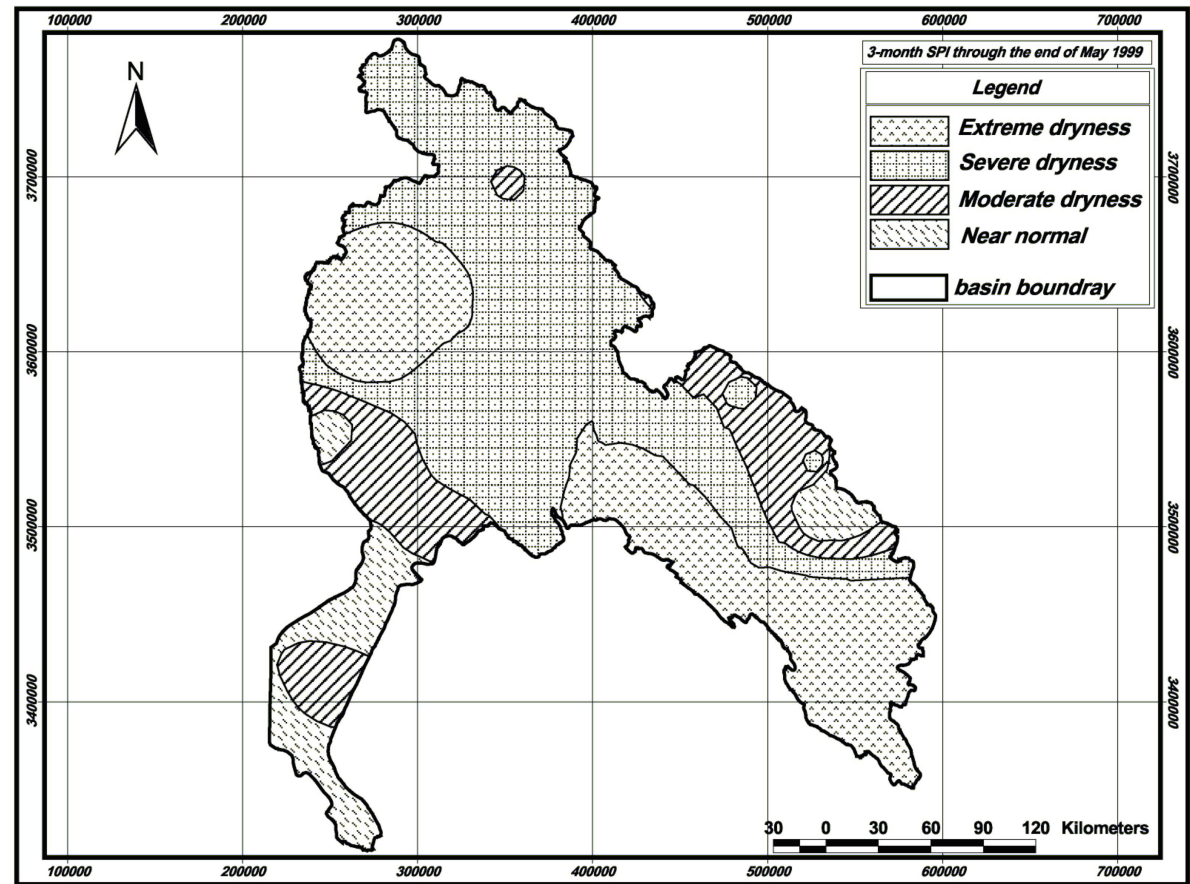

\section{Intensity-Duration- \\ Frequency and \\ spatial analysis of droughts}

M. Mohseni Saravi et al.

Title Page

Abstract

Introduction

Conclusions

References

Tables

Figures

14

$\rightarrow$

4

Back

Close

Full Screen / Esc

Printer-friendly Version

Interactive Discussion 


\section{HESSD}

6, 1347-1383, 2009

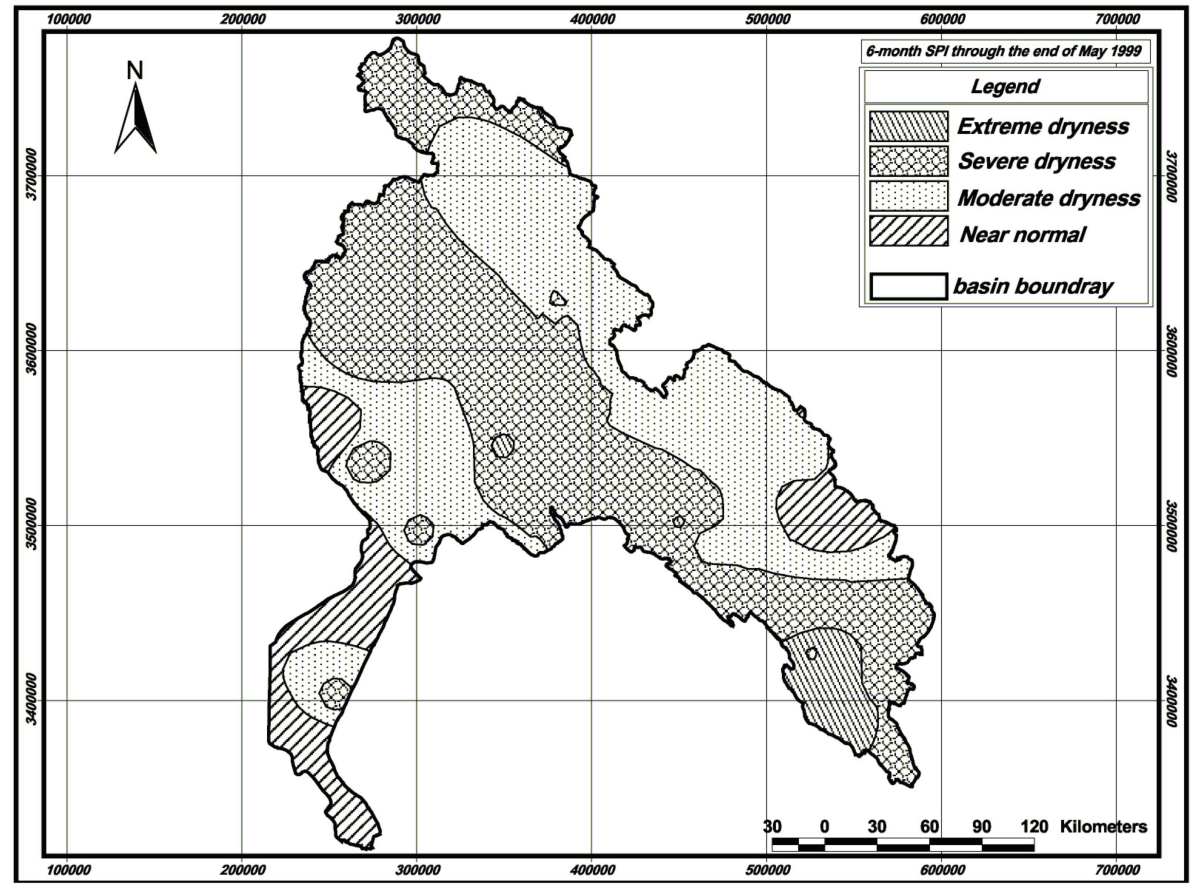

\section{Intensity-Duration- \\ Frequency and spatial analysis of droughts}

M. Mohseni Saravi et al.

Title Page

Abstract

Introduction

Conclusions

References

Tables

Figures

14

$\rightarrow$

4

Back

Close

Full Screen / Esc

Fig. 8. 6-month SPI through the end of May 1999.

Printer-friendly Version

Interactive Discussion 


\section{HESSD}

6, 1347-1383, 2009

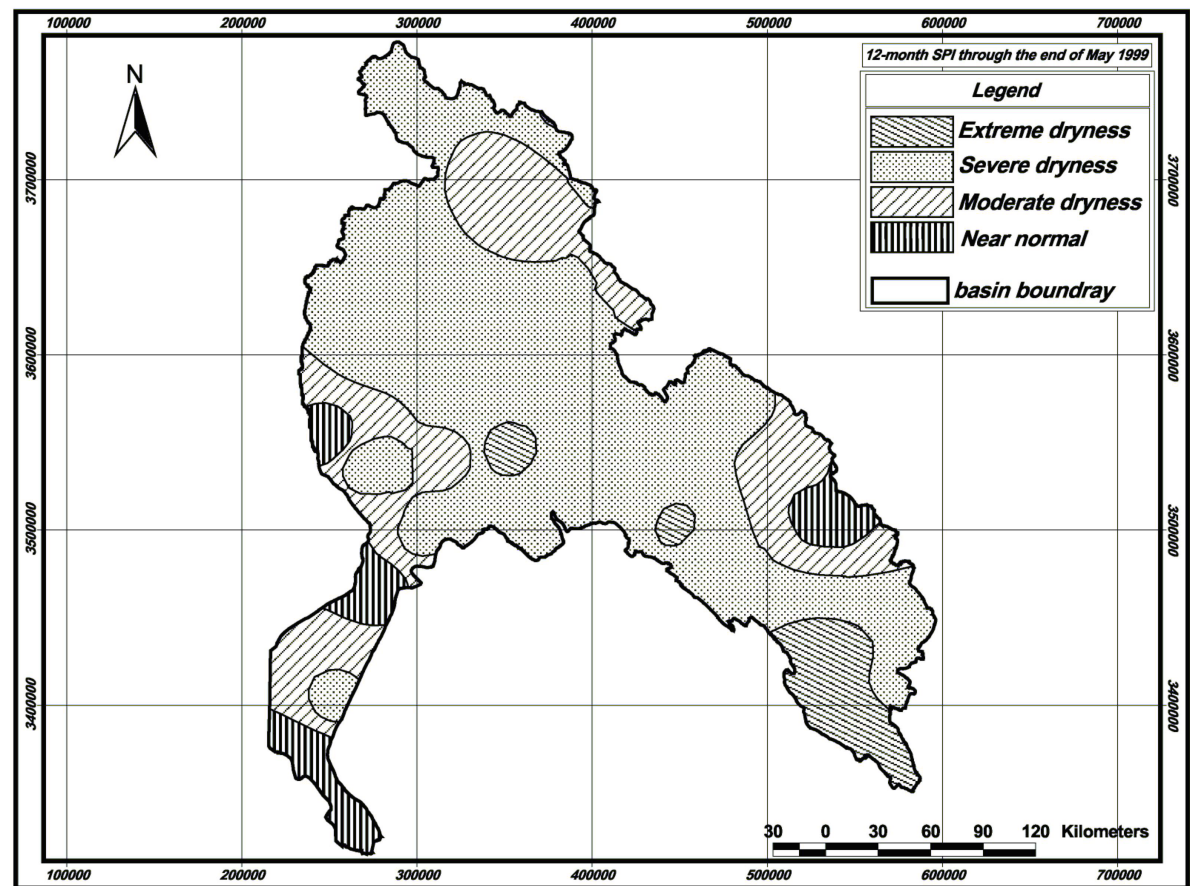

\section{Intensity-Duration- \\ Frequency and \\ spatial analysis of droughts}

M. Mohseni Saravi et al.

Title Page

Abstract

Introduction

Conclusions

References

Tables

Figures

14

$\rightarrow$

4

Back

Close

Full Screen / Esc

Printer-friendly Version

Interactive Discussion 


\section{HESSD}

6, 1347-1383, 2009

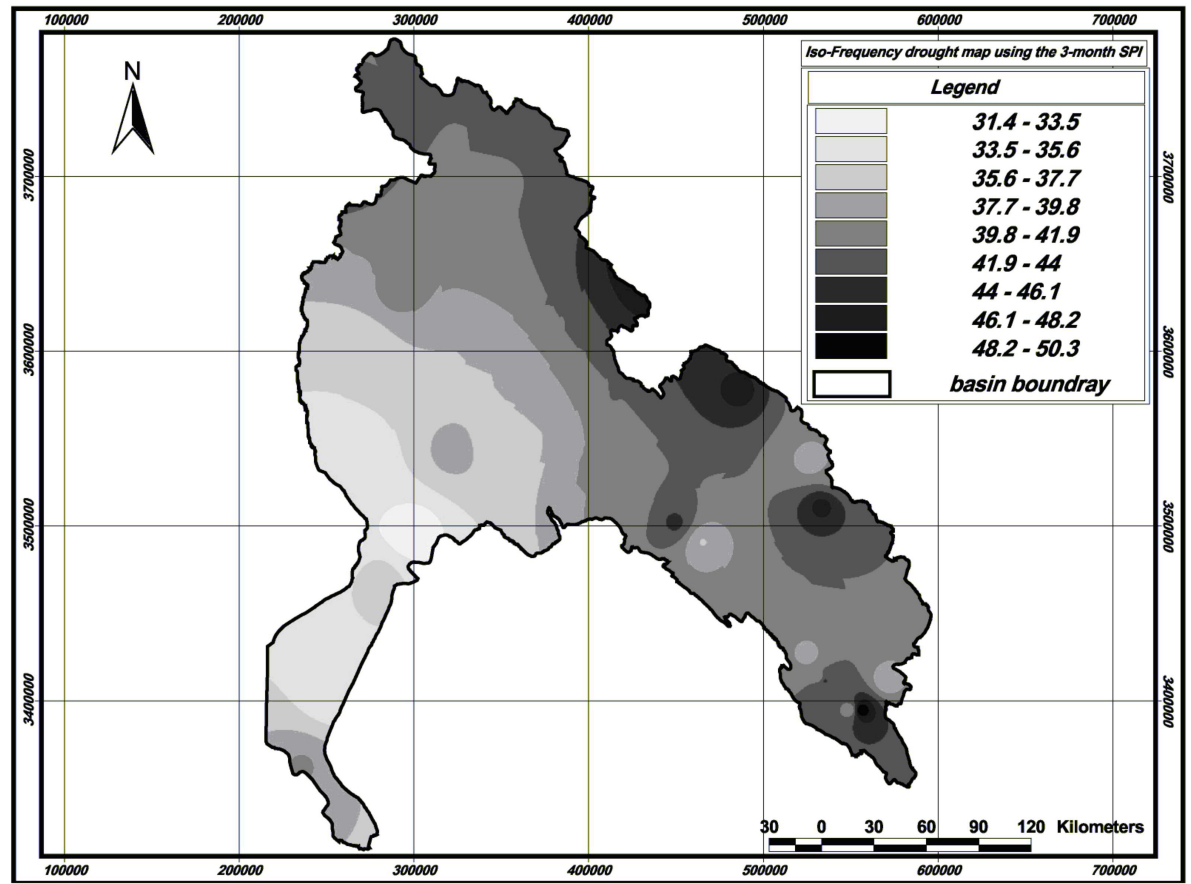

\section{Intensity-Duration- \\ Frequency and \\ spatial analysis of droughts}

M. Mohseni Saravi et al.

\section{Title Page}

Abstract

Introduction

Conclusions

References

Tables

Figures

14

$\rightarrow$

4

Back

Close

Full Screen / Esc

Printer-friendly Version

Interactive Discussion 


\section{HESSD}

6, 1347-1383, 2009

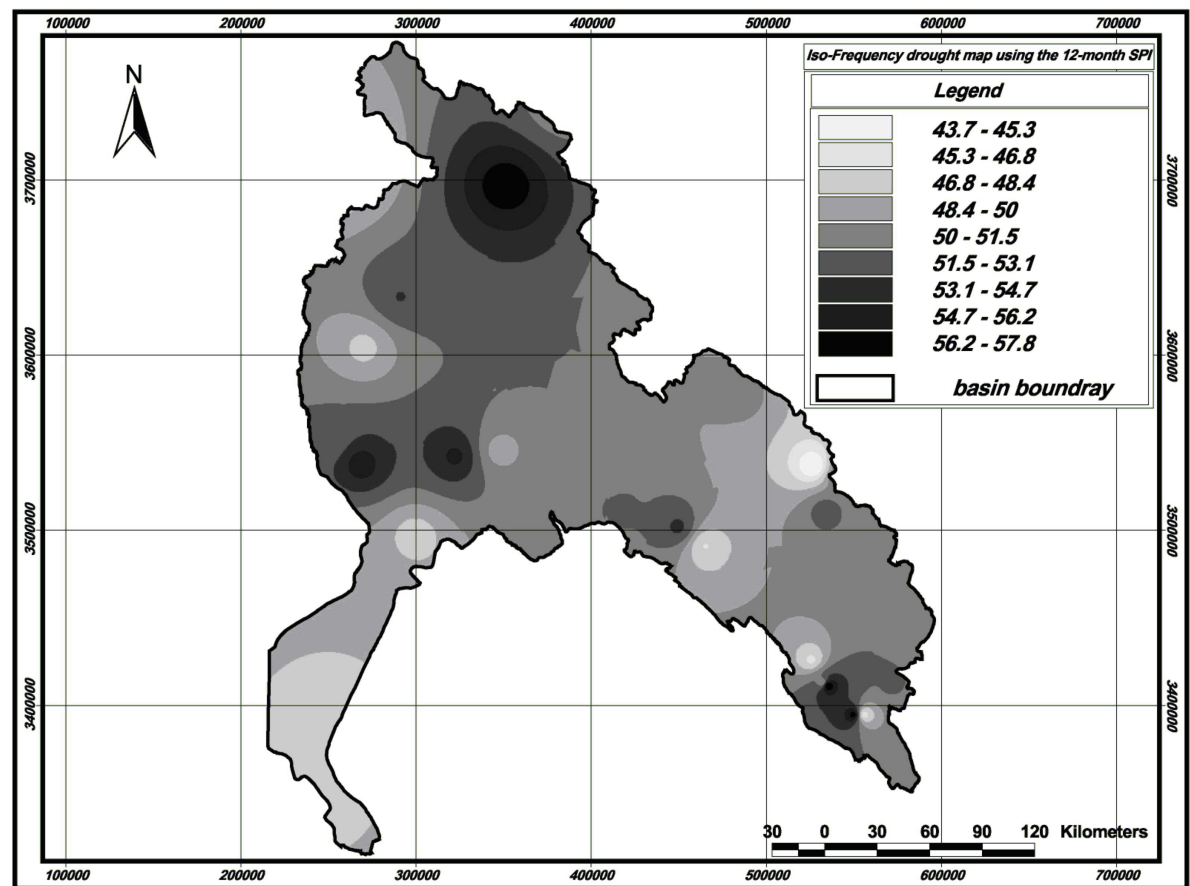

\section{Intensity-Duration- \\ Frequency and \\ spatial analysis of droughts}

M. Mohseni Saravi et al.

\section{Title Page}

Abstract

Introduction

Conclusions

References

Tables

Figures

14

$\rightarrow$

4

Back

Close

Full Screen / Esc

Printer-friendly Version

Interactive Discussion 


\section{HESSD}

6, 1347-1383, 2009

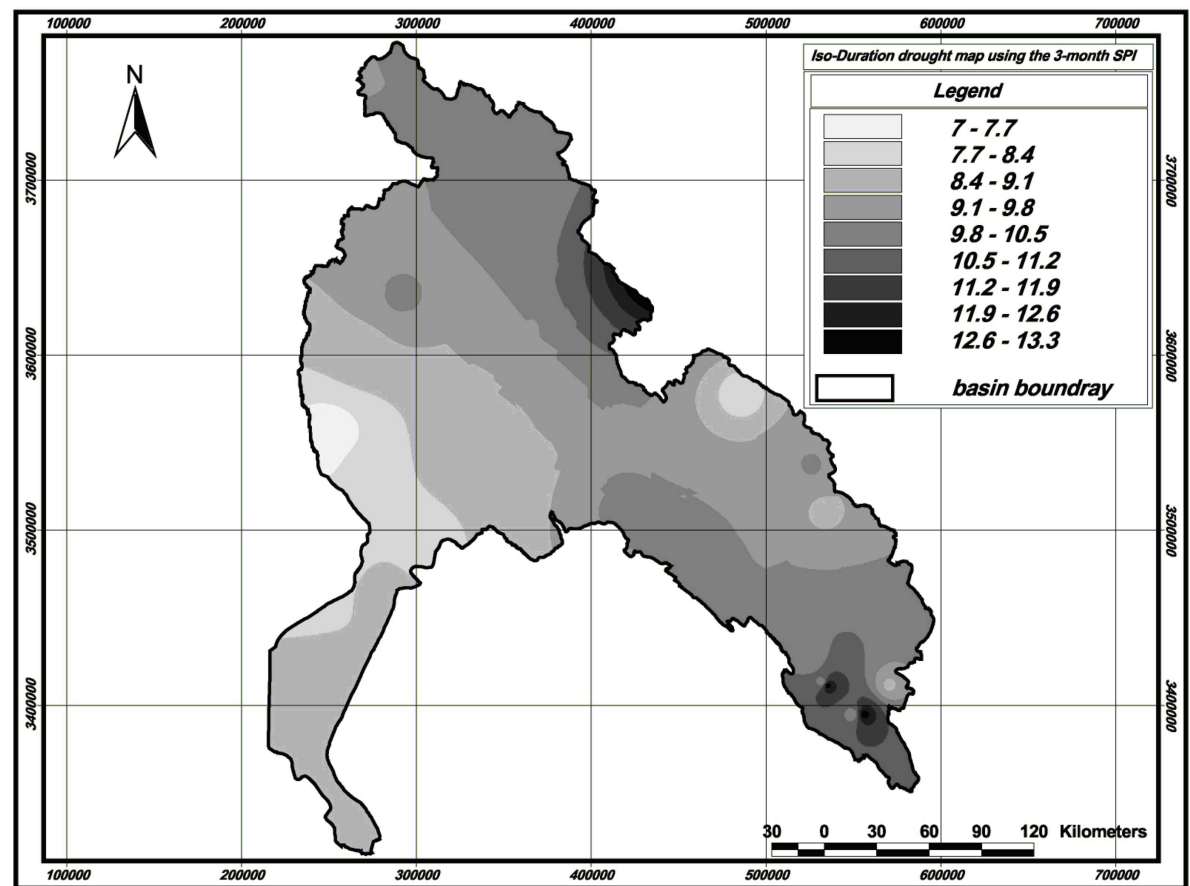

\section{Intensity-Duration- \\ Frequency and \\ spatial analysis of droughts}

M. Mohseni Saravi et al.

\section{Title Page}

Abstract

Introduction

Conclusions

References

Tables

Figures

14

$\rightarrow$

4

Back

Close

Full Screen / Esc

Printer-friendly Version

Interactive Discussion 


\section{HESSD}

6, 1347-1383, 2009

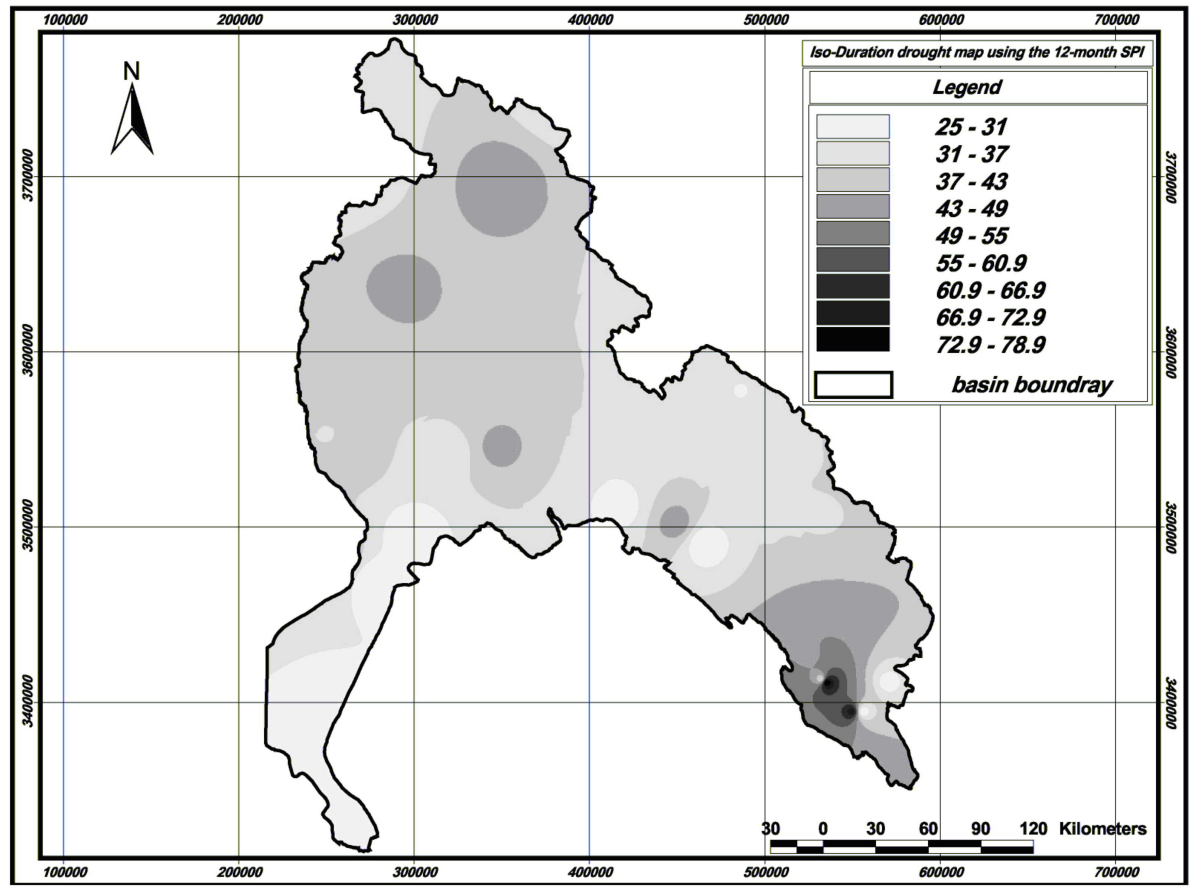

\section{Intensity-Duration- \\ Frequency and \\ spatial analysis of droughts}

M. Mohseni Saravi et al.

\section{Title Page}

Abstract

Introduction

Conclusions

References

Tables

Figures

14

$\rightarrow$

4

Back

Close

Full Screen / Esc

Printer-friendly Version

Interactive Discussion 


\section{HESSD}

6, 1347-1383, 2009

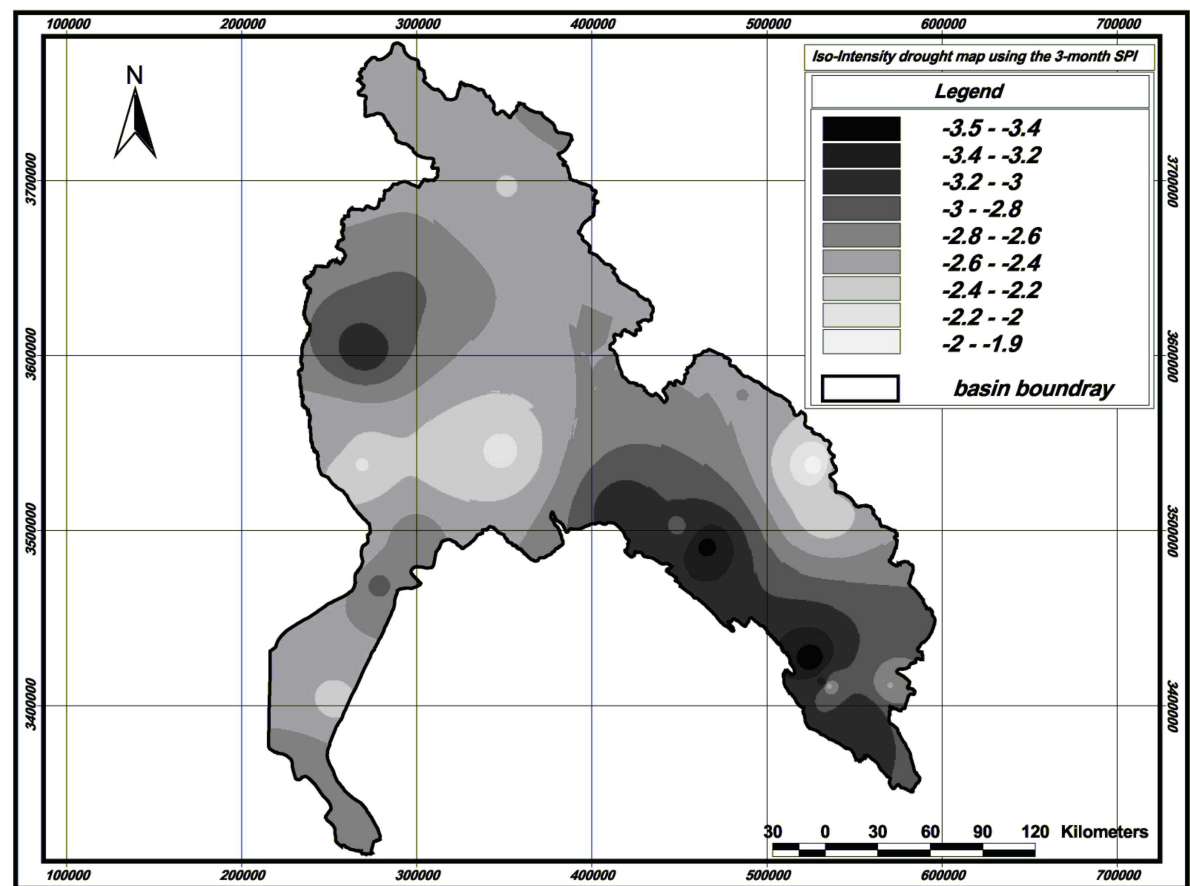

\section{Intensity-Duration- \\ Frequency and \\ spatial analysis of droughts}

M. Mohseni Saravi et al.

\section{Title Page}

Abstract

Introduction

Conclusions

References

Tables

Figures

14

$\rightarrow$

4

Back

Close

Full Screen / Esc

Printer-friendly Version

Interactive Discussion 


\section{HESSD}

6, 1347-1383, 2009

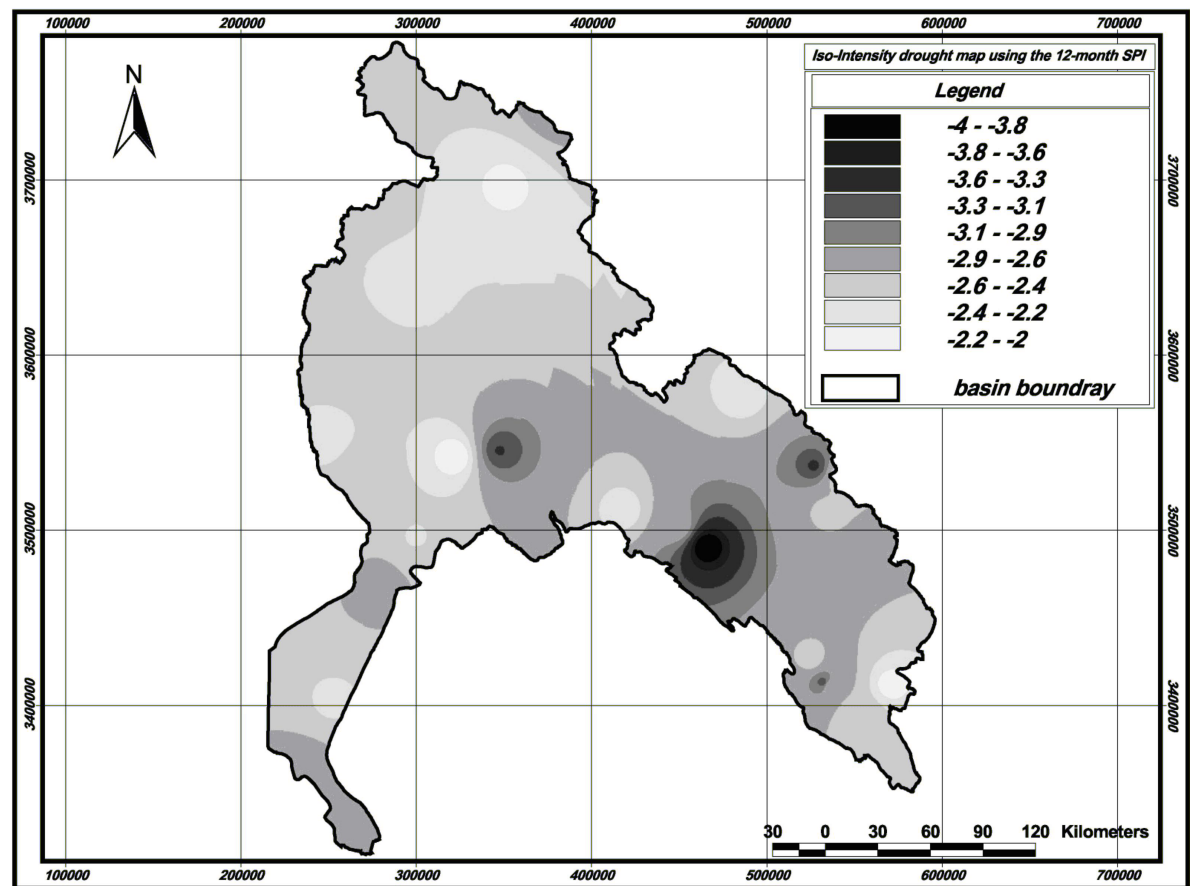

\section{Intensity-Duration- \\ Frequency and \\ spatial analysis of droughts}

M. Mohseni Saravi et al.

\section{Title Page}

Abstract

Conclusions

Tables

14

4

Back

Full Screen / Esc

Printer-friendly Version

Interactive Discussion 


\section{HESSD}

6, 1347-1383, 2009

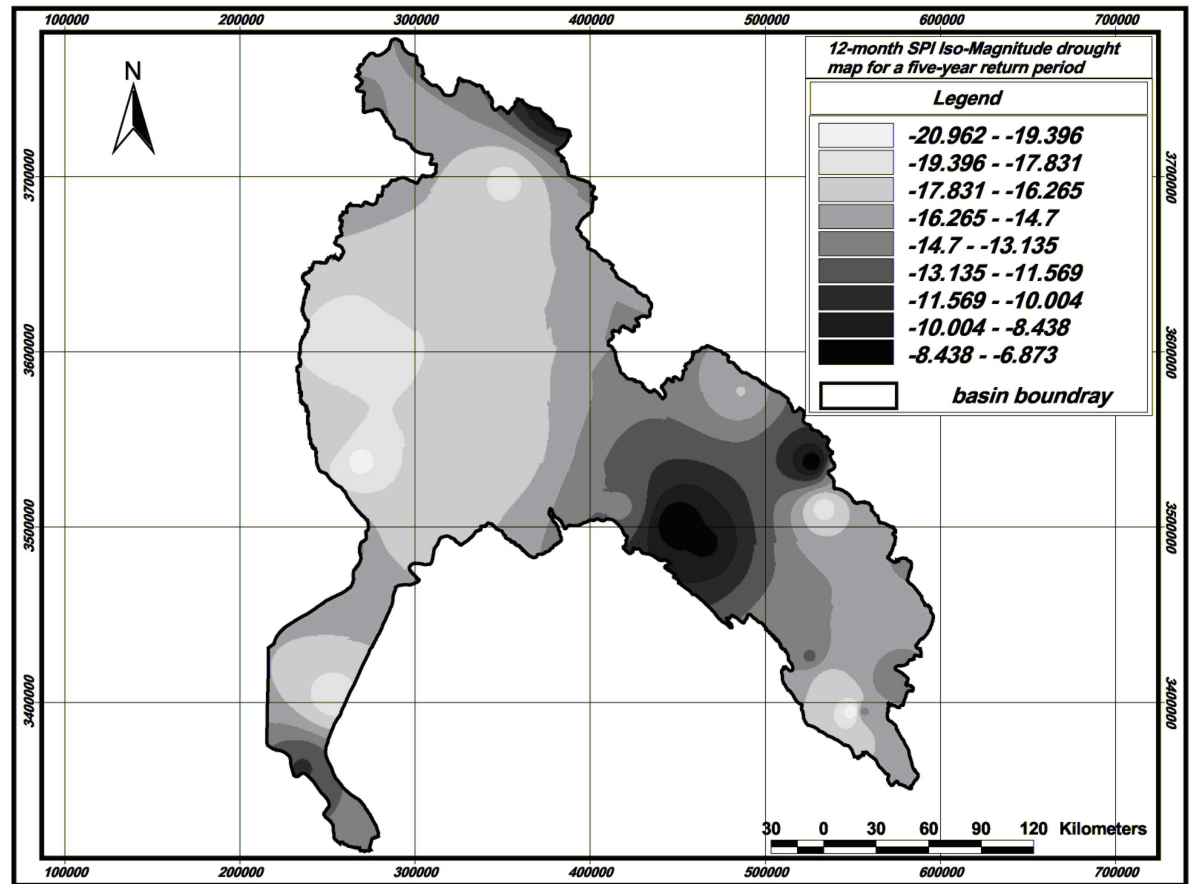

\section{Intensity-Duration- \\ Frequency and \\ spatial analysis of droughts}

M. Mohseni Saravi et al.

\section{Title Page}

Abstract

Introduction

Conclusions

References

Tables

Figures

14

$\rightarrow$

4

Back

Close

Full Screen / Esc

Printer-friendly Version

Interactive Discussion 


\section{HESSD}

6, 1347-1383, 2009

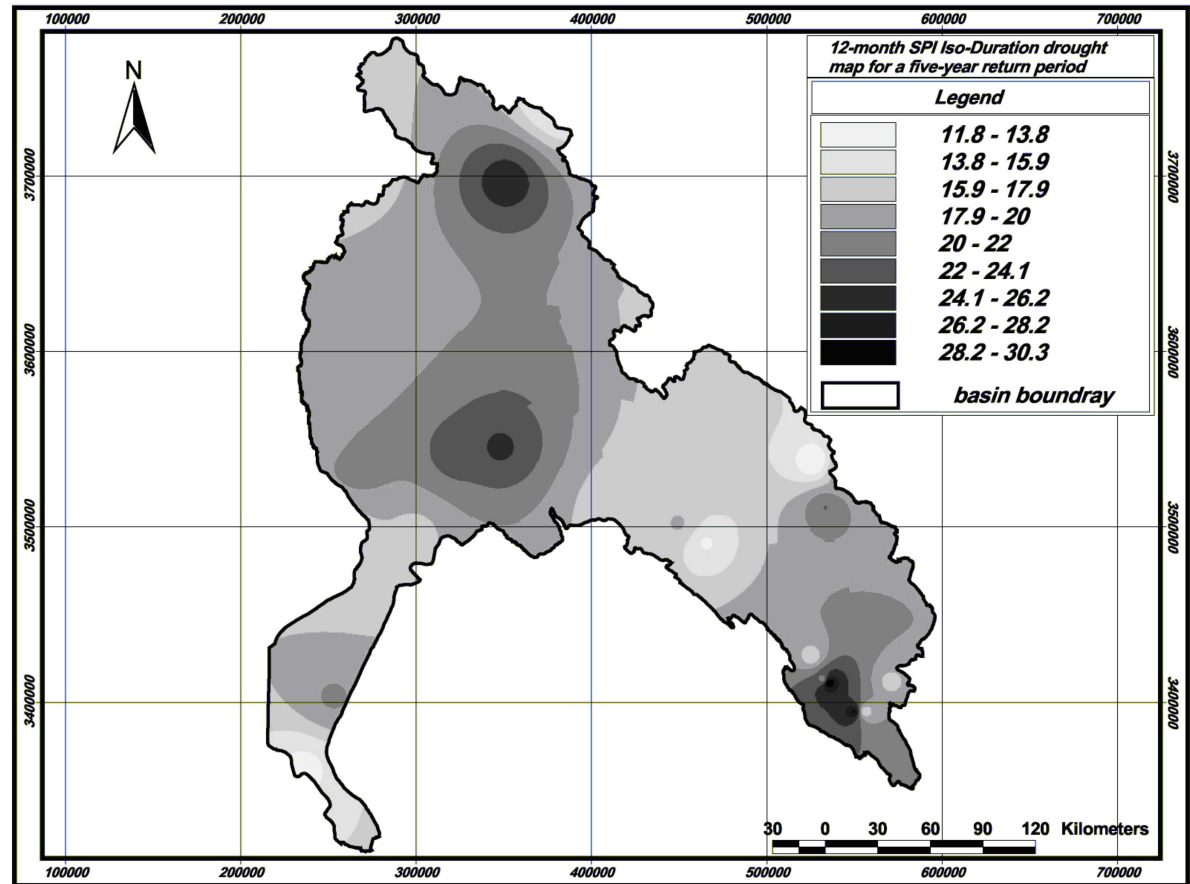

\section{Intensity-Duration- \\ Frequency and \\ spatial analysis of droughts}

M. Mohseni Saravi et al.

\section{Title Page}

Abstract

Conclusions

Tables

14

Back

Full Screen / Esc

Printer-friendly Version

Interactive Discussion 